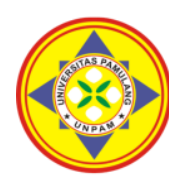

\title{
PENGARUH DISIPLIN TERHADAP KINERJA KARYAWAN PADA PT. FIRST MEDIA TBK CABANG FATMAWATI JAKARTA SELATAN
}

\author{
${ }^{1}$ Metalia Sari, ${ }^{2 *}$ Elizabeth Tika Kristina Hartuti \\ Universitas Pamulang, Tangerang, Banten, Indonesia \\ *dosen01503@unpam.ac.id
}

\begin{abstract}
Abstrak
Penelitian ini bertujuan untuk mengetahui seberapa besar pengaruh disiplin terhadap kinerja karyawan pada PT. First Media Tbk Cabang Jakarta Selatan Fatmawati secara parsial dan simultan. Metode yang digunakan adalah metode kuantitatif. Teknik Sampling yang digunakan adalah dengan sampel jenuh mengguanakan sampel sebanyak 60 responden. Hasil penelitian ini adalah pengaruh yang kuat antara disiplin $(X)$ terhadap kinerja karyawan $(Y)$ dengan regresi $\mathrm{Y}=12,424+0.682 \mathrm{X}$, Uji hipotesis diperoleh $\mathrm{t}$ hitung $>\mathrm{t}$ tabel atau $(8,012>1,671)$. Dengan demikian $\mathrm{H}_{0}$ ditolak dan $\mathrm{H}_{\mathrm{a}}$ diterima artinya terdapat pengaruh signifikan antara Disiplin Terhadap Kinerja Karyawan Pada PT.First Media Tbk Cabang Jakarta Selatan Fatmawati.
\end{abstract}

Kata Kunci: Disiplin dan Kinerja Karyawan.

\section{Abstract}

This study aims to determine how much influence discipline has on employee performance at PT. First Media Tbk, Fatmawati South Jakarta Branch partially and simultaneously. The method used is a quantitative method. The sampling technique used is a saturated sample using a sample of 60 respondents. The results of this study are a strong influence between discipline $(X)$ on employee performance $(Y)$ with regression $Y=12.424+$ $0.682 X$. Hypothesis test obtained $t$ count $>t$ table or $(8,012>1,671)$. Thus HO is rejected and Ha is accepted, meaning that there is a significant influence between Discipline on Employee Performance at PT. First Media Tbk, Jakarta Selata Fatmawatin Branch.

Keywords: Discipline and Employee Performance.

\section{PENDAHULUAN}

Kedisiplinan kerja dalam sebuah perusahaan dapat membuat karyawan menjalankan tugasnya dengan baik, seorang karyawan yang disiplin dan patuh terhadap norma-norma yang berlaku dalam perusahaan dapat meningkatkan produktivitas serta prestasinya. Menurut Hasibuan (2012:198) ada beberapa faktor yang harus diperhatikan dalam penerapan disiplin seperti: ketepatan waktu, menggunakan peralatan kantor dengan baik, tanggung jawab yang tinggi dan ketaatan pada aturan perusahaan. Namun pada kenyataannya masih terdapat karyawan yang kurang disiplin dalam sebuah perusahaan. Acuan kedisiplinan adalah Tujuan dan kemampuan, teladan pimpinan, balas jasa, keadilan, waksat (pengawasan melekat), sanksi hukuman, ketegasan, dan hubungan kemanusiaan.

Kinerja (performance) dari akar kata " to perform" yang mempunyai arti melakukan, menjalankan, melaksanakan. Arti kata performance merupakan kata benda (noun) dimana salah satu arti adalah "thing done" (sesuatu hasil yang telah dikerjakan).

Upaya dalam peningkatan kinerja karyawan pada perusahaan ini dapat diwujudkan dengan menetapkan disiplin pada karyawan. Karena disiplin karyawan pada PT. First Media Tbk. Cabang Jakarta Selatan Fatmawati masih rendah.

Untuk mengatasi masalah yang ada pada PT.First Media TBK maka solusinya adalah menerapkan disiplin.

Adapun langkah-langkah yang dapat diambil agar tercipta kedisiplinan di lingkungan perusahaan yaitu: 
1. Memberikan kompensasi, besar atau kecilnya jumlah kompensasi yang diberikan dapat mempengaruhi disiplin kerja. Para karyawan cenderung akan mematuhi segala peraturan apabila ia merasa kerja kerasnya akan mendapat imbalan yang sesuai dengan jerih payah yang diberikan oleh pimpinan, apabila para karyawan memperoleh kompensasi yang memadai, mereka akan bekerja dengan tekun disertai dengan perasaan senang.

2. Keteladanan pimpinan, keteladanan pimpinan sangat dibutuhkan oleh setiap bawahan diorganisasi manapun. Pimpinan merupakan panutan, ia adalah tempat bersandar bagi para bawahannya. Pemimpin yang bisa memberikan teladan akan mudah menerapkan disiplin kerja bagi karyawannya. begitu pula sebaliknya, pemimpin yang buruk akan sulit mengadakan disiplin kerja bagi para bawahannya. Oleh karena itulah, pemimpin harus dapat menjadi contoh yang baik bagi para karyawannya jika menginginkan disiplin kerja yang sesuia dengan harapan.

3. Aturan yang pasti, disiplin kerja tidak akan terwujud tanpa adanya aturan pasti yang dapat menjadi pedoman bagi bawahannya dalam menjalankan tugasnya. Aturan yang tidak jelas kepastiannya tidak akan mungkin bisa terwujud dalam perilaku bawahannya. Setiap bawahan tidak akan percaya pada setiap aturan yang berubah-ubah dan tidak jelas kepastiannya. Aturan yang pasti ialah aturan yang dibuat tertulis yang dapat menjadi pedoman bagi karyawan dan tidak berubah-ubah karena situasi dan kondisi.

4. Keberanian seorang pimpinan dalam mengambil tindakan, apabila terdapat pelanggaran disiplin kerja, pimpinan harus memiliki keberanian untuk menyikapi sesuai dengan aturan yang menjadi pedoman bersama. Pimpinan tidak boleh bertindak diskriminasi dalam menangani pelanggaran disiplin kerja.
5. Pengawasan pimpinan, Pengawasan sangat diperlukan untuk memastikan segala kegiatan berjalan sesuai dengan standar peraturan. Pengawasan yang lemah memberi kesempatan bawahan untuk lebih berani melanggar dan mengabaikan peraturan. Pengawasan sangat penting mengingat sifat dasar manusia yang ingin bebas tanpa terikat oleh aturan.

6. Perhatian kepada para karyawan, perhatian karyawan tidak hanya perhatian tentang kompensasi yang besar, tetapi perlu juga perhatian dari atasannya. Kesulitan-kesulitan yang dihadapi karyawan sanantiasa ingin didengar dan selanjutnya diberikan masukan oleh pimpinan, pimpinan yang suka memberikan perhatian kepada pegawainya akan menciptakan kehangatan hubungan kerja antara atasan dengan bawahannya. Pimpinan yang semacam itu akan dihormati dan dihargai oleh bawahannya. Karyawan yang segan dan hormat kepada pimpinan akan memiliki disiplin kerja yang sesungguhnya. Yaitu, disiplin kerja yang penuh kesadaran dan kerelaan dalam menjalankannya.

7. Kebiasaan-kebiasaan yang mendukung tegaknya disiplin, kebiasaan-kebiasaan positif itu, diantaranya mengucapkan salam dan berjabat tangan apabila bertemu, saling menghargai aturan sesama rekan, memberitahu saat meninggalkan tempat kerja kepada rekan.

\section{TINJAUAN PUSTAKA}

Kedisiplinan merupakan fungsi operasional manajemen sumber daya manusia yang terpenting karena semakin baik disiplin kerja pegawai, semakin baik kinerja yang dapat dicapai. Tanpa disiplin yang baik, sulit bagi organisasi untuk mencapai hasil yang optimal. Kedisiplinan merupakan faktor yang utama yang diperlukan sebagai alat peringatan terhadap pegawai yang tidak mau berubah sifat dan perilakunya. Sehingga seorang pegawai dikatakan memiliki disiplin yang 
baik jika pegawai tersebut memiliki rasa tanggung jawab terhadap tugas yang diberikan kepadanya.

Berikut adalah pengertian-pengertian disiplin kerja menurut para ahli diantaranya yaitu:

Menurut Hasibuan (2006:444) bahwa: "Disiplin kerja adalah kesadaran dan kerelaan seseorang dalam menaati semua peraturan perusahaan dan norma-norma sosial yang berlaku."

Menurut Rivai (2011:825) bahwa: “Disiplin kerja adalah suatu alat yang dipergunakan para manajer untuk berkomunikasi dengan karyawan agar mereka bersedia untuk mengubah suatu perilaku serta sebagai suatu upaya untuk meningkatkan kesadaran dan kesedian seorang dalam memenuhi segala peraturan perusahaan."

Menurut Prof. Dr. Moeheriono, M.Si. dalam bukunya yang berjudul "Pengukuran Kinerja Berbasis Kompetensi", kinerja karyawan merupakan hasil kinerja yang dapat dicapai oleh seseorang atau kelompok orang dalam suatu organisasi baik secara kualitatif maupun secara kuantitatif, sesuai dengan kewenangan, tugas, dan tanggung jawab masing-masing dalam upaya mencapai tujuan organisasi bersangkutan secara legal, tidak melanggar hukum, dan sesuai dengan moral ataupun etika. Seluruh kegiatan yang dilakukan untuk meningkatkan bisnis perusahaan atau organisasi merupakan bentuk kinerja.

Peran karyawan sangat penting terhadap sukses atau tidaknya perusahaan. Perusahaan dalam hal ini perlu memantau kinerja setiap karyawannya apakah mereka sudah melaksanakan tugas dan kewajibannya sesuai harapan. Penilaian kinerja ini sangat penting untuk menentukan apakah perusahaan akan terus melakukan kerja sama dengan karyawan jika kinerjanya baik, atau sebaliknya memutus hubungan kerja jika performa karyawan tidak sesuai harapan.

\section{METODE}

Dalam penelitian ini populasinya adalah karyawan PT. First Media Tbk Cabang Jakarta Selatan Fatmawati sebanyak 60 responden.

\section{HASIL DAN PEMBAHASAN}

Berdasarkan hasil analisis regresi berfungsi untuk mengetahui pengaruh variabel independen terhadap variabel dependen. Dalam hal ini disiplin berpengaruh signifikan terhadap kinerja karyawan dengan persamaan regresi $\mathrm{Y}=$ $12,242+0.682 \mathrm{X}$, angka koefisien regresi sebesar +0.682 yang berarti setiap penambahan $1 \%$ disiplin berpengaruh positif sebesar 0.682. Sedangkan nilai disiplin korelasi sebesar 0,725 artinya kedua variabel memiliki tingkat hubungan yang kuat dengan koefisien determinasi sebesar $52,5 \%$. Uji hipotesis diperoleh $\mathrm{t}$ hitung $>\mathrm{t}$ tabel atau $(8,012>1,671)$. Dengan demikian $\mathrm{H}_{0}$ ditolak dan $\mathrm{H}_{\mathrm{a}}$ diterima artinya terdapat pengaruh signifikan antara disiplin terhadap kinerja karyawan di PT.First Media Tbk Cabang Jakarta Selata Fatmawatin.

\section{KESIMPULAN}

Disiplin yang ada di PT. First Media Tbk Cabang Jakarta Selatan tergolong dalam kategori sangat baik hal ini dilihat dari rata-rata variabel X ( disiplin) 4,24 yang berada pada interval sangat baik. Namun sanksi hukuman berada pada indikator paling rendah dibanding indikator lainnya dengan pernyataan "pimpinan PT.First Media Tbk Cabang Jakarta Selata Fatmawatin tranparansi dalam memberikan sanksi hukuman". Skor dari pernyataan tersebut adalah 3,39 Hal ini menunjukan bahwa kurangnya kedisiplinan dalam hal pemberian sanksi hukum.

Kinerja karyawan PT.first Media Tbk tergolong sangat baik hal ini dapat dilihat dari rata-rata variabel Y ( kinerja ) 4,426 yang berada pada interval sangat baik. Namun terdapat 2 pernyataan yang nilainya paling rendah dengan skor 3,39 yaitu pada indikator tanggung jawab 
dengan pernyataan "Karyawan PT.First Media Tbk Cabang Jakarta Selata Fatmawatin paham akan tanggung jawab yang diberikan oleh pimpinan" dan pada indikator kuantitas "Karyawan PT.First Media Tbk Cabang Jakarta Selata Fatmawatin masuk kerja tepat waktu.". Hal ini menunjukan kinerja yang diberikan karyawan belum optimal pada PT. First Media Tbk Cabang Jakarta Selatan.

Berdasarkan hasil perhitungan nilai korelasi sederhana sebesar $r=0,725$ artinya ada pengaruh yang kuat anatara disiplin $(X)$ terhadap kinerja karyawan (Y) dengan regresi $\mathrm{Y}=12,424+0.682 \mathrm{X}$, angka koofisien regresi sebersar 0.682 . sedangkan nilai koofisien korelasi yang berarti disiplin berpengaruh positif sebesar 0,682. Nilai koofisien determinasi sebesar sebesar $0.525 \%$ sedangkan sisanya sebesar $47,5 \%$ dipengaruhi oleh faktor lain. Uji hipotesis diperoleh thitung > dari $t$ tabel atau 8,012 > 1,671 dengan demikian $\mathrm{H}_{0}$ ditolak dan $\mathrm{H}_{a}$ diterima artinya terdapat pengaruh yang signifikan antara disiplin terhadap kinerja karyawan pada PT.First Media Tbk Cabang Jakarta Selata Fatmawati.

\section{DAFTAR PUSTAKA}

Afandi, P. (2018). Manajemen Sumberdaya Manusia Teori Konsep Dan Indikator. Pekanbaru: Zanafa Publishing.

AM, E. N., Sarwani, S., Akbar, I. R., Mas' adi, M., \& Maddinsyah, A. Pengaruh Kedisiplinan Dan Pemberian Kesejahteraan Terhadap Kinerja Pegawai Pada Unit Pelaksana Teknis Puskesmas Wilayah Tangerang Selatan. JENIUS (Jurnal Ilmiah Manajemen Sumber Daya Manusia), 4(2), 185-200.

Arikunto, S. (2016). Prosedur Penelitian: Suatu Pendekatan Praktik. Jakarta: Rineka Cipta

Dessler, G. (2015). Manajemen Sumber Daya Manusia. Jakarta: Salemba Empat.

Ghozali, I. \& Ratmono, D. (2017). Analisis Multivariat Dan Ekonometrika Dengan Eviews 10. Badan Penerbit Universitas Diponegoro: Semarang.
Hasibuan, M.S.P. (2016). Manajemen Sumber Daya Manusia. Edisi Revisi. Jakarta: Penerbit PT Bumi Aksara.

Hasibuan, MS.P.(2017). Manajemen Sumber Daya Manusia. Edisi Revisi. Jakarta: Bumi Aksara.

Istijanto, F. (2010). Aplikasi Praktis Riset Pemasaran. Jakarta: Gramedia.

Kasmir. (2015). Analisis Laporan Keuangan. Jakarta : PT Raja Grafindo Persada.

Mangkunegara, A.P. (2015). Sumber Daya Manusia Perusahaan. Cetakan Kedua Belas. Remaja Rosdakarya:Bandung

Mangkunegara, A.P. (2016). Manajemen Sumber Daya Manusia Perusahaan. Bandung : PT. Remaja Rosdakarya.

Mangkunegara, A.P. (2017). Manajemen Sumber Daya Manusia Perusahaan, Bandung : Remaja Rosdakarya.

Robbins, P. S \& Coulter, M. (2015). Manajemen, Diterjemahkan Oleh Bob Sabran, Wibi Hardani. Erlangga:Jakarta.

Rozi, A., \& Sunarsi, D. (2020). The Influence of Motivation and Work Experience on Employee Performance at PT. Yamaha Saka Motor in South Tangerang. Jurnal Office, 5(2), 65-74.

Sofyan, S., Prasada, D., \& Akbar, I. R. (2020). Pengaruh Motivasi, Lingkungan Kerja dan Kepuasan Kerja Terhadap Kinerja Guru SMP/MTs Muhammadiyah Cabang Sawangan. Jurnal Ilmu Komputer dan Bisnis, 11 (2a), 33-44.

Sugiyono (2015). Metode Penelitian Kombinasi (Mix Methods). Bandung: Alfabeta

Sunarsi, D. (2019). Penerapan MSDM Strategis Dalam Upaya Meningkatkan Kemampuan Organisasi dalam menyongsong Revolusi 4.0. Jurnal Ilmiah MEA (Manajemen, Ekonomi, \& Akuntansi), 3(1), 221-233.

Supangat, A. Th, Statistika Dalam Kajian Deskriptif, Inferensi, Dan Nonparametik, Bandung: Kencana Penada Media Group.

Suparno, E.P. (2015). Manajemen Pengembangan Sumber Daya Manusia.Yogyakarta: PUSTAKA PELAJAR. 